Louisiana State University

LSU Digital Commons

Faculty Publications

Department of Biological Sciences

4-1-2019

\title{
A 5-lipoxygenase-specific sequence motif impedes enzyme activity and confers dependence on a partner protein
}

\author{
Erin E. Schexnaydre \\ Louisiana State University \\ Jana Gerstmeier \\ Friedrich Schiller Universität Jena \\ Ulrike Garscha \\ Friedrich Schiller Universität Jena \\ Paul M. Jordan \\ Friedrich Schiller Universität Jena \\ Oliver Werz \\ Friedrich Schiller Universität Jena
}

See next page for additional authors

Follow this and additional works at: https://digitalcommons.Isu.edu/biosci_pubs

\section{Recommended Citation}

Schexnaydre, E., Gerstmeier, J., Garscha, U., Jordan, P., Werz, O., \& Newcomer, M. (2019). A

5-lipoxygenase-specific sequence motif impedes enzyme activity and confers dependence on a partner protein. Biochimica et Biophysica Acta - Molecular and Cell Biology of Lipids, 1864 (4), 543-551.

https://doi.org/10.1016/j.bbalip.2018.09.011

This Article is brought to you for free and open access by the Department of Biological Sciences at LSU Digital Commons. It has been accepted for inclusion in Faculty Publications by an authorized administrator of LSU Digital Commons. For more information, please contact ir@lsu.edu. 


\section{Authors}

Erin E. Schexnaydre, Jana Gerstmeier, Ulrike Garscha, Paul M. Jordan, Oliver Werz, and Marcia E. Newcomer 


\title{
A 5-lipoxygenase-specific sequence motif impedes enzyme activity and confers dependence on a partner protein
}

\author{
Erin E. Schexnaydre ${ }^{\mathrm{a}}$, Jana Gerstmeier ${ }^{\mathrm{b}}$, Ulrike Garscha ${ }^{\mathrm{b}}$, Paul M. Jordan ${ }^{\mathrm{b}}$, Oliver Werz ${ }^{\mathrm{b}}$, \\ Marcia E. Newcomer ${ }^{\mathrm{a}, *}$ \\ ${ }^{a}$ Department of Biological Sciences, Louisiana State University, Baton Rouge, LA, USA \\ ${ }^{\mathrm{b}}$ Pharmaceutical/Medicinal Chemistry, Institute of Pharmacy, Friedrich-Schiller-University Jena, 07743 Jena, Germany
}

\section{A R T I C L E I N F O}

\section{Keywords:}

Lipoxygenase

Eicosanoids

Arachidonic acid

Leukotriene $\mathrm{A}_{4}$

FLAP

Enzyme regulation

\begin{abstract}
A B S T R A C T
Leukotrienes (LT) are lipid mediators of the inflammatory response that play key roles in diseases such as asthma and atherosclerosis. The precursor leukotriene $\mathrm{A}_{4}\left(\mathrm{LTA}_{4}\right)$ is synthesized from arachidonic acid (AA) by 5-lipoxygenase (5-LOX), a membrane-associated enzyme, with the help of 5-lipoxygenase-activating protein (FLAP), a nuclear transmembrane protein. In lipoxygenases the main chain carboxylate of the C-terminus is a ligand for the non-heme iron and thus part of the catalytic center. We investigated the role of a lysine-rich sequence (KKK ${ }^{653-655}$ ) 20 amino acids upstream of the C-terminus unique to 5-LOX that might displace the main-chain carboxylate in the iron coordination sphere. A 5-LOX mutant in which KKK ${ }^{653-655}$ is replaced by ENL was transfected into HEK293 cells in the absence and presence of FLAP. This mutant gave $\sim 20$-fold higher 5-LOX product levels in stimulated HEK cells relative to the wild-type 5-LOX. Co-expression of the enzymes with FLAP led to an equalization of 5-LOX products detected, with wild-type 5-LOX product levels increased and those from the mutant enzyme decreased. These data suggest that the KKK motif limits 5-LOX activity and that this attenuated activity must be compensated by the presence of FLAP as a partner protein for effective LT biosynthesis.
\end{abstract}

\section{Introduction}

The biosynthesis of leukotrienes (LT), lipid mediators of the inflammatory response, is initiated by 5-lipoxygenase (5-LOX) [1,2]. 5LOX translocates to the nuclear membrane upon intracellular $\mathrm{Ca}^{2+}$ mobilization $[3,4]$, along with phospholipase $\mathrm{A}_{2}\left(\mathrm{PLA}_{2}\right)$. PLA $\mathrm{A}_{2}$ cleaves arachidonic acid (AA) from phospholipids that form the nuclear bilayer so that it is then available for 5-LOX to be converted to $\mathrm{LTA}_{4}$. Additionally, 5-LOX requires a helper protein, termed 5-lipoxygenase-activating protein (FLAP), a nuclear membrane-embedded AA-binding protein that facilitates substrate access and promotes completion of the two-step transformation of AA to $\mathrm{LTA}_{4}$ [5-8]. This transformation proceeds via (i) hydrogen abstraction at $\mathrm{C} 7$ and the oxygenation of AA at C5 and (ii) hydrogen abstraction from the 5-hydroperoxyeicosatetraenoic acid (5-HPETE) intermediate at C10 to generate LTA $_{4}[9,10]$ (Fig. S1). 5-LOX and FLAP co-localize at the nuclear membrane and are suggested to interact in order for FLAP to efficiently transfer AA as substrate to 5-LOX [11-14].

5-LOX is a short-lived enzyme [15-18], as is fitting for an enzyme that initiates the synthesis of inflammatory mediators that activate G- protein coupled receptors at nanomolar concentrations [19-21]. The effects of overproduction of 5-LOX-generated lipid mediators are exhibited in pathologies such as asthma and atherosclerosis. Auto-inactivation has been proposed to play an important regulatory role in temporal control of 5-LOX activity [22,23].

In the course of constructing a 5-LOX mutant amenable to structural studies we found that replacement of $\mathrm{KKK}^{653-655}$ with its counterpart from a stable 5-LOX homologue (i.e. ENL) improved in vitro stability. This variant was also trimmed of its membrane-insertion loops and two Cys-residues near the active site and was given the moniker Stable-5LOX [24]. The structural basis for $\mathrm{KKK}^{653-655}$-invoked instability was easy to rationalize: the presence of K655 (where LOX homologues have a highly conserved Leu) positions a charged amino acid for repulsion with the invariant R651 (Fig. 1). The carboxy termini of LOXs insert into the catalytic domains so that the terminal, backbone carboxyl serves as a ligand for the catalytic iron. The 5-LOX KKK motif lies in the turn that allows the main chain carboxyl to circle back and ligate the catalytic iron.

We replaced the $\mathrm{KKK}^{653-655}$ sequence with ENL, the sequence present in a typical lipoxygenase with a robust catalytic activity $[25,26]$,

\footnotetext{
*Corresponding author at: Department of Biological Sciences, Louisiana State University, Baton Rouge, LA 70803, USA.

E-mail address: newcomer@1su.edu (M.E. Newcomer).
} 

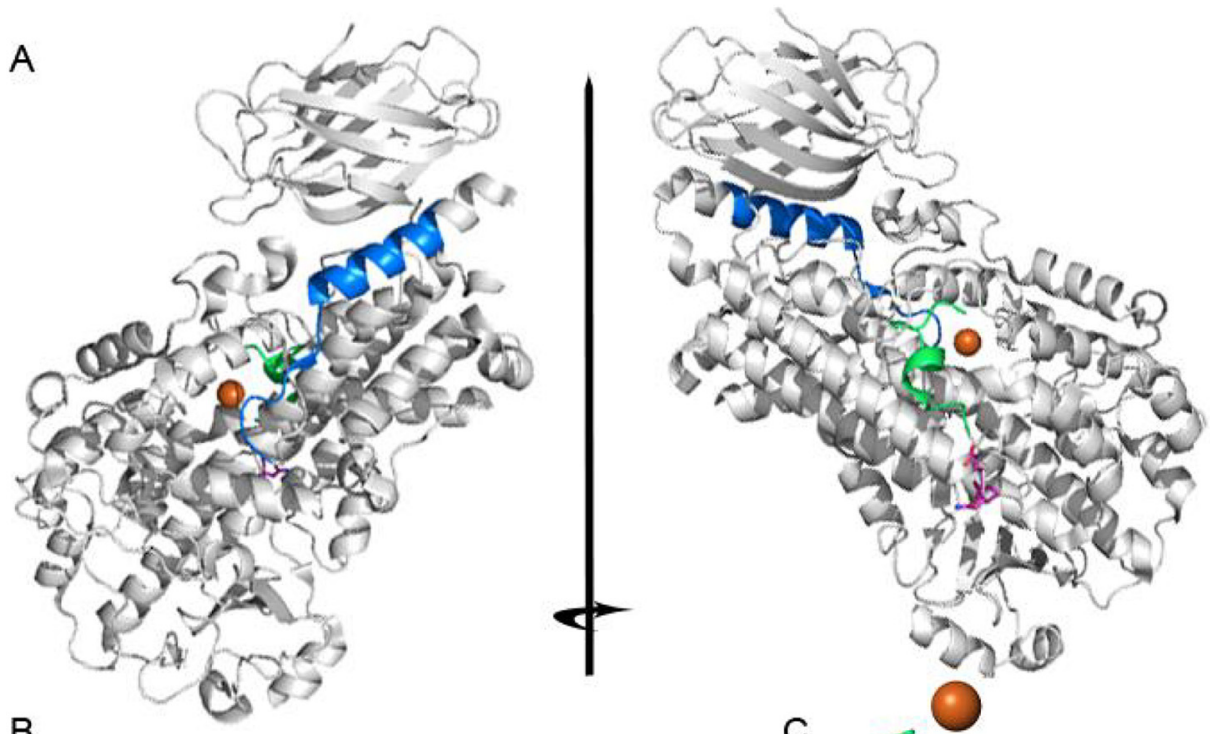

Fig. 1. Structural perspective of the $\mathrm{KKK}^{653-655}$ motif. A. Two 5-LOX cartoon diagrams related by a $180^{\circ}$ rotation. The "Tail" and "Body" antibody epitopes are highlighted in green and blue, respectively. The mutant residues (ENL) that replace $\mathrm{KKK}^{653-655}$ are shown in stick rendering in magenta. B. Sequence comparison of human 5-LOX and other LOXs highlighting the conserved Arg651 (blue) and the unique 5-LOX Lys655 where there is a highly conserved Leu (magenta). C. The KKK ${ }^{653-655}$ sequence is located at the turn between the C-terminal helix and carboxy-terminus, which is a ligand for the catalytic non-heme iron. The "Tail" epitope (green), and the conserved Arg and Leu (blue and magenta) are depicted.

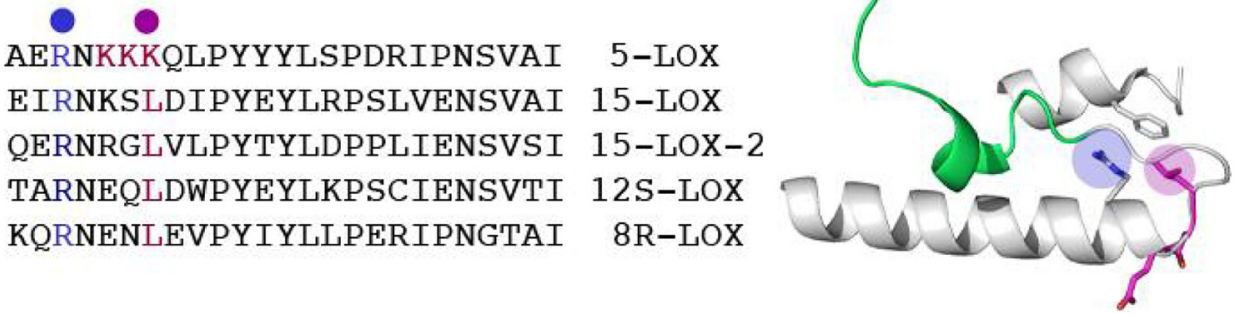

AERNKKKQLPYYYLSPDRIPNSVAI 5-LOX EIRNKSLDIPYEYLRPSLVENSVAI 15-LOX QERNRGLVLPYTYLDPPLIENSVSI 15-LOX-2 TARNEQLDWPYEYLKPSCIENSVTI 12S-LOX KQRNENLEVPYIYLLPERIPNGTAI 8R-LOX into a WT-5-LOX expression construct (yielding the so-called Triple-KMutant-5-LOX, TKM-5-LOX) to investigate the role of this KKK motif. We observed that HEK cells expressing TKM-5-LOX display a $\sim 20$-fold increase of 5-LOX product formation relative to the wild-type enzyme. In parallel experiments with $\mathrm{Ca}^{2+}$-ionophore-stimulated cells we see an accelerated loss of the TKM-5-LOX, being subject to turnover-based inactivation like WT-5-LOX [16]. However, when co-expressed with FLAP, 5-LOX products detected in HEK cells for the mutant and wildtype enzyme are equivalent. Our data suggest that the KKK motif is a governor of 5-LOX enzyme activity and the helper protein FLAP is required to sufficiently relieve its auto-suppression for effective LT synthesis. Moreover, substrate sequestering and/or handoff by FLAP may limit the rate of $\mathrm{LTA}_{4}$ synthesis by the hyperactive TKM-mutant.

\section{Results}

\subsection{Substitution of the KKK ${ }^{653-655}$ motif stabilizes 5-LOX against proteolysis}

In order to establish that the mutation of KKK to ENL did not inadvertently disrupt the 5-LOX protein fold, we subjected both the purified wild-type and mutant enzymes to limited proteolysis by chymotrypsin. The enzymes were incubated with the protease in the absence and presence of $\mathrm{Ca}^{2+}$. TKM-5-LOX exhibited a higher resistance to cleavage by chymotrypsin than WT-5-LOX when the proteins were assessed with two distinct antibodies: one specific for the C-terminal twelve amino acids ("Tail") and the other for the amino acids 130-149 ("Body") (Fig. 2, antibody epitopes highlighted in Fig. 1). Essentially, little to none of the full-length enzyme was detected by either antibody when purified WT-5-LOX was incubated with chymotrypsin, implying its completed proteolysis. In contrast, in these same conditions the TKM-5-LOX remained largely intact. The major band detected for the TKM-5-LOX after exposure to protease is likely to be full-length enzyme given that it is recognized by an antibody raised to the C-terminal peptide and migrates at the same molecular weight as the purified enzyme.

The TKM-5-LOX is also more resistant to chymotrypsin in crude cell lysates. Intact HEK cells expressing WT- or TKM-5-LOX (but not FLAP) were first treated with (or without) $\mathrm{Ca}^{2+}$-ionophore A23187. Cell lysates were prepared and incubated with and without chymotrypsin. The proteins (fragments) of the incubations were analyzed by Western blot using the Tail antibody. It is important to note that the cleavage bands observed in samples incubated without chymotrypsin demonstrate the enzyme's susceptibility to endogenous cellular proteases upon cell lysis, as the experiments were free of protease inhibitors. Fragments detected for WT-5-LOX are more pronounced than in the lysates of TKM-5-LOXexpressing cells (Fig. 3).

\subsection{Co-localization of 5-LOX and FLAP at the nuclear membrane appears unaffected by substitution of the KKK motif}

Immunofluorescence microscopy studies indicate that like the wildtype enzyme [11,27], the TKM-5-LOX variant translocates to the nuclear membrane upon stimulation with $\mathrm{Ca}^{2+}$-ionophore, both in the absence and presence of FLAP (Fig. 4). Detection by both "Body" and "Tail" antibody demonstrated that TKM-5-LOX colocalizes with FLAP, as seen for the wild-type enzyme (Fig. S2). Additionally, the TKM-5LOX displays the same cytoplasmic localization as WT-5-LOX when unstimulated. Representative immunofluorescence images are presented in Fig. 4.

\subsection{HEK cells expressing TKM-5-LOX yield elevated levels of 5-LOX products}

TKM-5-LOX was expressed in HEK293 cells at levels comparable to the WT-5-LOX, as judged by mRNA and protein levels, detected by qPCR (Fig. S3) and Western blotting, respectively (vida infra, Section 2.5). 5-LOX-expressing HEK cells devoid of FLAP were incubated with 


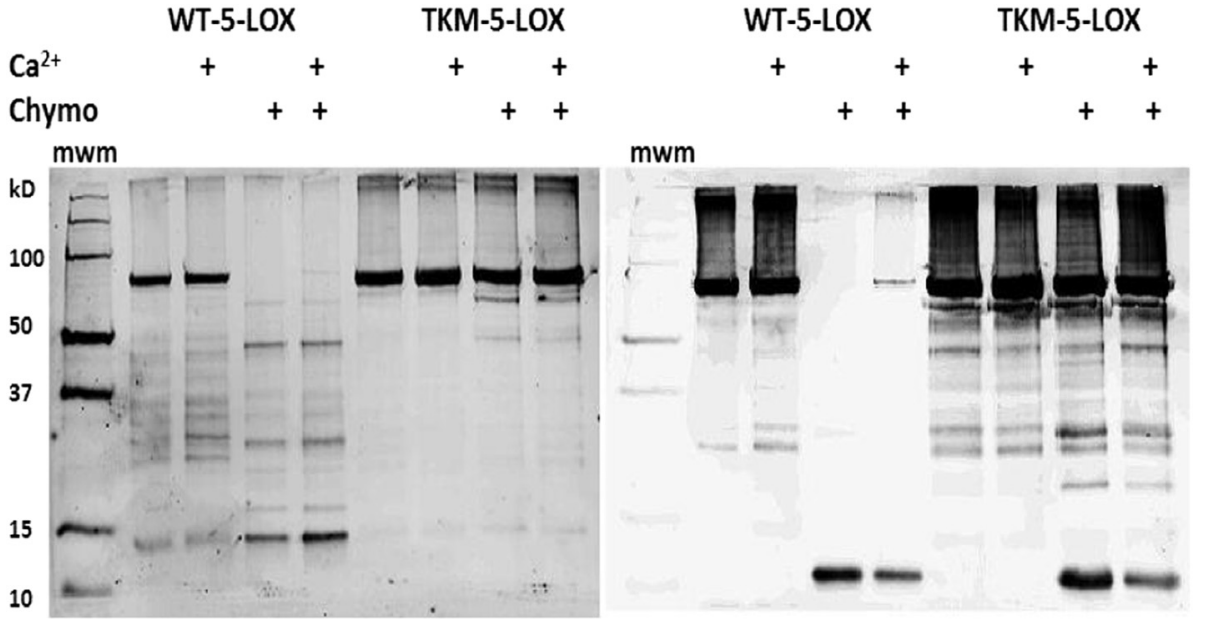

Fig. 2. In vitro chymotrypsin cleavage analysis. WT5-LOX and TKM-5-LOX cleavage patterns with "Body" (left) or "Tail" (right) antibody development, $\pm \mathrm{Ca}^{2+}$ and/or chymotrypsin. WT-5LOX displays susceptibility to chymotrypsin cleavage, while TKM-5-LOX is strikingly more resistant. The lane containing the molecular weight markers is labelled "mwm."

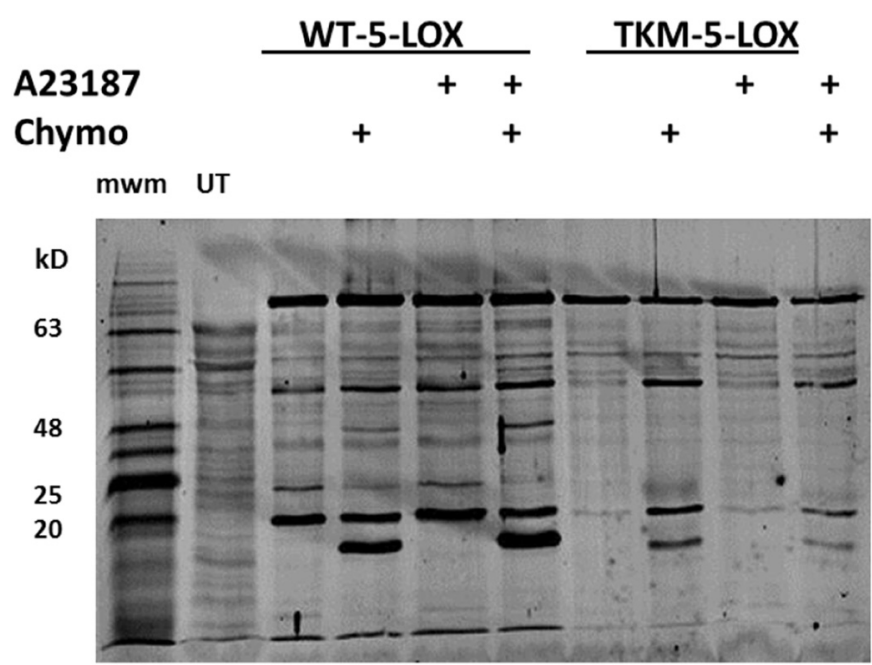

Fig. 3. Chymotrypsin cleavage patterns of WT-5-LOX or TKM-5-LOX in lysates of HEK cells. Cells were first treated with or without $\mathrm{Ca}^{2+}$-ionophore (A21387), lysed, incubated with or without chymotrypsin, and then developed with the "Tail" primary antibody. Lanes labelled "mwm" and "UT" correspond to the molecular weight markers and lysates of untransfected cells, respectively. Note the intensity of the lower molecular weight band generated by chymotrypsin for the WT-5-LOX relative to the full-length protein band.

or without $\mathrm{Ca}^{2+}$-ionophore and $3 \mu \mathrm{M}$ AA was added at $5 \mathrm{~min}$. At this concentration of AA the bulk of the substrate is expected to partition into the bilayer and is accessible to 5-LOX when translocated to the membrane. Both the final $\mathrm{LTA}_{4}$ hydrolysis products (combined as LT) and the intermediate were quantitated by high-pressure liquid chromatography (HPLC) analyses. The 5-HPETE intermediate is detected as the reduced alcohol 5-hydroxyeicosatetraenoic acid (5-HETE). As expected, 5-LOX product formation was only detected in cells stimulated with $\mathrm{Ca}^{2+}$-ionophore. In the absence of FLAP, TKM-5-LOX-expressing cells yielded strikingly higher overall product levels ( $\sim 190$ ng 5-HETE, $\sim 65 \mathrm{ng}$ LT) compared to WT-5-LOX cells ( $\sim 9 \mathrm{ng} 5$-HETE, $\sim 3 \mathrm{ng}$ LT, Fig. 5). However, the proportion of $\mathrm{LTA}_{4}$ hydrolysis products relative to 5 -HETE is roughly the same $(\sim 33 \%)$. This $\sim 20$-fold higher product formation cannot be explained by elevated protein expression levels and suggests that TKM-5-LOX has significantly augmented, or prolonged, enzyme activity over WT-5-LOX.

\subsection{Co-expression of FLAP reduces product formation of TKM-5-LOX to the levels of WT-5-LOX}

In parallel experiments and in agreement with previous findings
[27], co-expression of FLAP in HEK cells together with 5-LOX caused a $\sim 4$ fold increase in product formation by WT-5-LOX [27] (Fig. 5). In contrast, co-expression of FLAP reduced product formation of TKM-5LOX down to the levels of WT-5-LOX (TKM $53 \mathrm{ng}$ 5-HETE, $28 \mathrm{ng}$ LTs; WT 43 ng 5-HETE; 23 ng LTs). Thus, the presence of FLAP elevates the activity of WT-5-LOX but attenuates the increased activity of the TKM mutant in these assay conditions.

In addition, we compared the kinetics of product formation in HEK cells co-expressing FLAP and WT- or TKM-5-LOX. Ultra Performance Liquid Chromatography (UPLC)-MS/MS analysis was performed with cells stimulated with ionophore and AA (added at $\mathrm{t}_{0}$ ) and 5-LOX products sampled at 30,60,120,180, 360 and $600 \mathrm{~s}$. Again, the presence of FLAP led to similar levels of products generated by both cells types, with no significant differences detected at early $(<300 \mathrm{~s})$ or late (600 s) time points when total 5-LOX products are summed (Fig. 6). Both cell lines reached the plateau for 5-LOX products at the same time points (180 s), indicating no differences in their ability to metabolize AA. When 5-HETE and LTB $_{4}$-breakdown products are plotted individually, the kinetics of 5-HETE production in the two cell lines agree more than those of LT production, with the latter at higher levels in the WT-5-LOX-expressing cells. However, again at $10 \mathrm{~min}$ the difference between the LT levels in the two cell types does not appear significant (Figs. 5, 6). These data support the conclusion that the presence of FLAP reduces TKM-5-LOX product formation to WT-5-LOX levels.

2.5. The substitution of KKK promotes loss of enzyme in conditions in which substrate is available

We next monitored 5-LOX protein levels in the HEK cells in order to investigate whether the increased product levels of the TKM-5-LOX might be a consequence of increased enzyme longevity (Fig. 7). Using a method adapted from that described by Dai et al. [28], 5-LOX protein levels (relative to the house-keeping protein GAPDH) in the presence of the protein synthesis inhibitor cycloheximide were monitored in HEK cells for $4 \mathrm{~h}$ by Western blot. These experiments were performed in the presence or absence of $\mathrm{Ca}^{2+}$-ionophore: in the presence of $\mathrm{Ca}^{2+}$-ionophore 5-LOX becomes activated and translocates to the nuclear membrane to access AA. It is important to point out that exogenous AA was not added to the incubation with cycloheximide, and that only endogenous AA (liberated by $\mathrm{PLA}_{2}$ upon $\mathrm{Ca}^{2+}$ ionophore stimulation) is available.

In the absence of $\mathrm{Ca}^{2+}$-ionophore, the levels of WT- and TKM-5-LOX remained roughly stable up to $4 \mathrm{~h}$, regardless of the presence of FLAP. In these conditions, the WT-5-LOX appears to be expressed at slightly elevated levels versus TKM-5-LOX (Fig. 7) (5-LOX/GAPDH ratios at $0.6 \pm 0.20$ for WT-5-LOX and $0.3 \pm 0.15$ for TKM-5-LOX). Upon $\mathrm{Ca}^{2+}$-ionophore stimulation of cells devoid of FLAP, the levels of the 


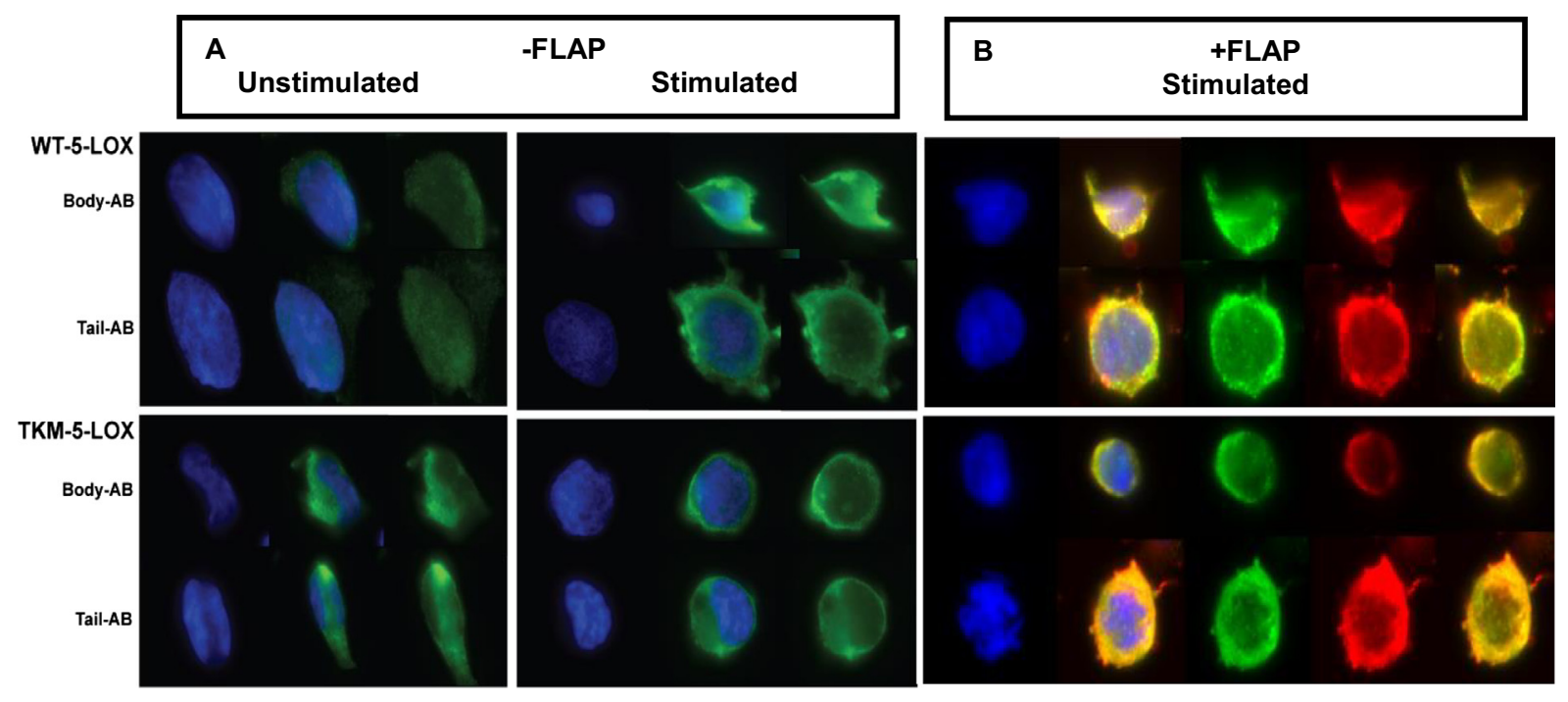

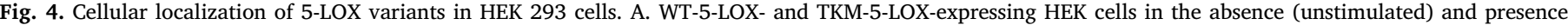

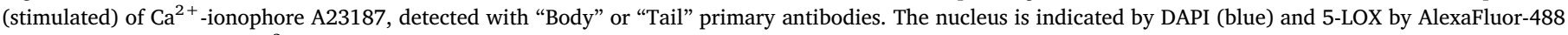

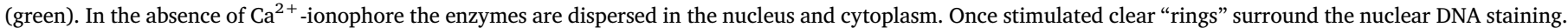

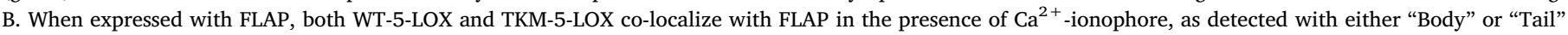

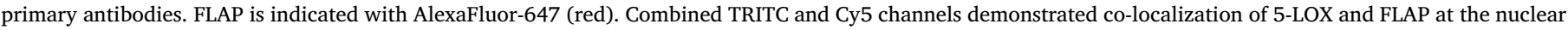
membrane as confirmed by ImageJ co-localization analysis. (Supplemental Fig. 2).

A

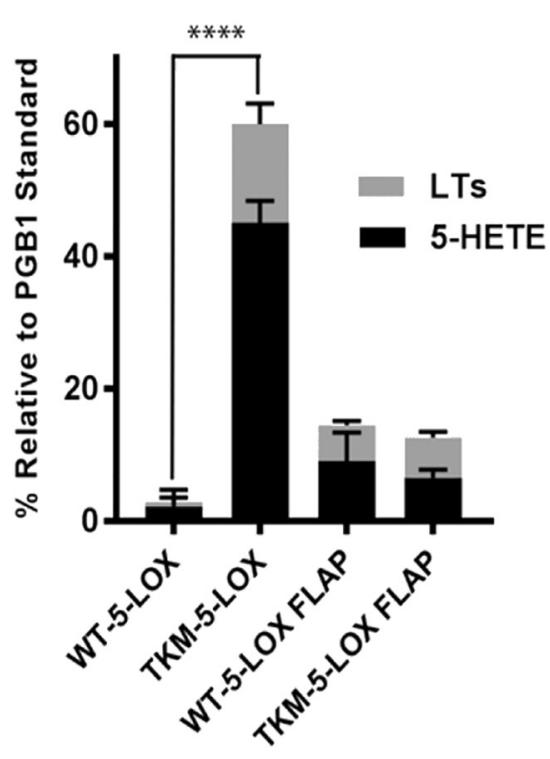

B

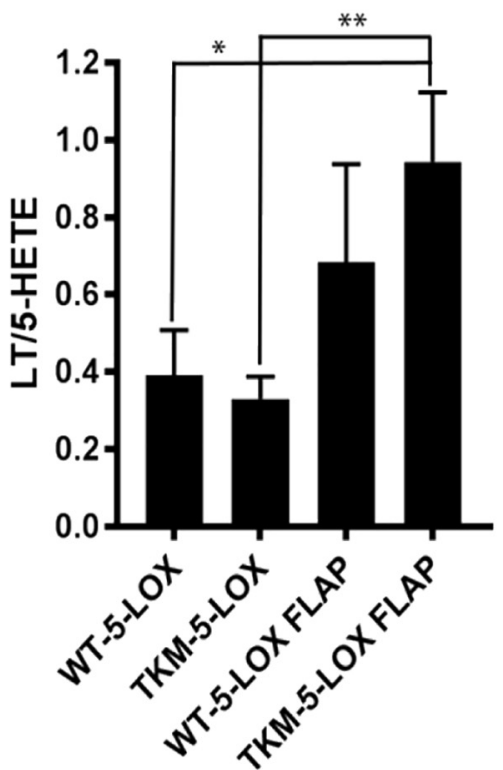

C

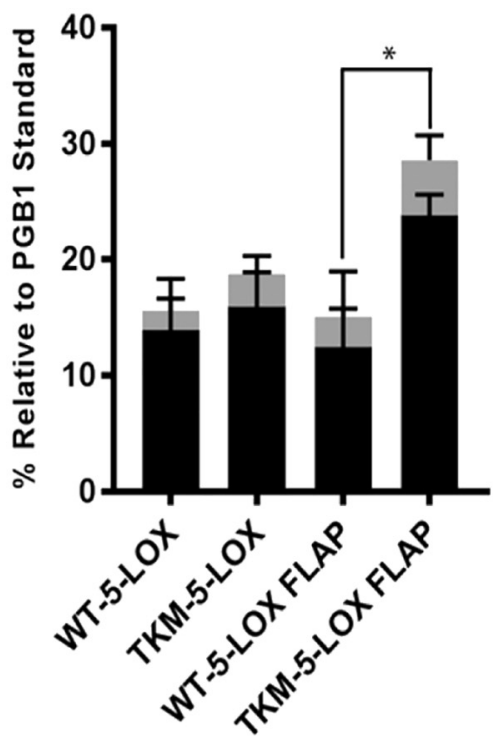

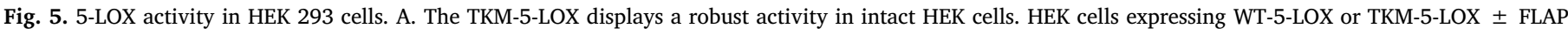

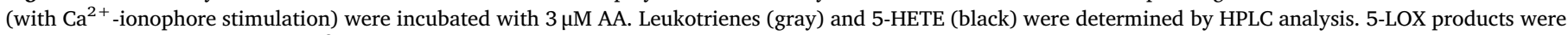

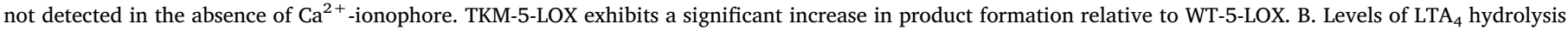

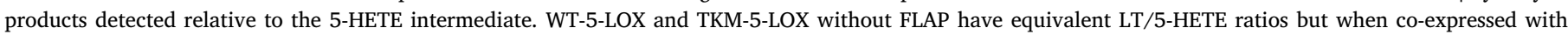

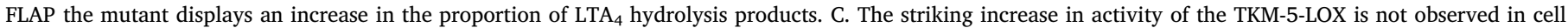

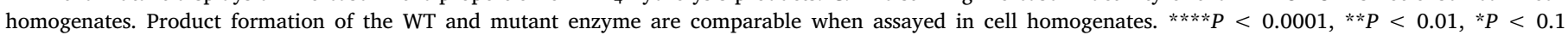
Statistical analysis performed with Graphpad Prism version 7.

TKM-5-LOX declined within $90 \mathrm{~min}$, while those for the WT-5-LOX much less so. The loss of TKM-5-LOX is consistent with its enhanced enzyme activity and turnover-based inactivation as previously described for 5-LOX [16]. In contrast, when co-expressed with FLAP, where 5-LOX product levels of WT- and TKM-5-LOX are comparable, the levels of TKM-5-LOX remain stable. These data suggest that the increase in product yields from TKM-5-LOX (without its partner FLAP) is not a consequence of a prologoned half-life for TKM-5-LOX, despite the enhanced in vitro stablity. Moreover, TKM-5-LOX levels decline in conditions in which it can produce 5-HETE or LTA $_{4}$.

Previous work indicated that 5-LOX products are only detected in the 5-LOX expressing HEK293 cells when exogenous arachidonic acid is added [27]. However, we confirmed the presence and availability of endogenous AA by increasing the sample size $\left(5 \times 10^{6}\right.$ vs. $1 \times 10^{6}$ cells). The UV spectrum displayed in Fig. 8 is consistent with the presence of LTA 4 hydrolysis products in extracts of HEK293 cells co- 

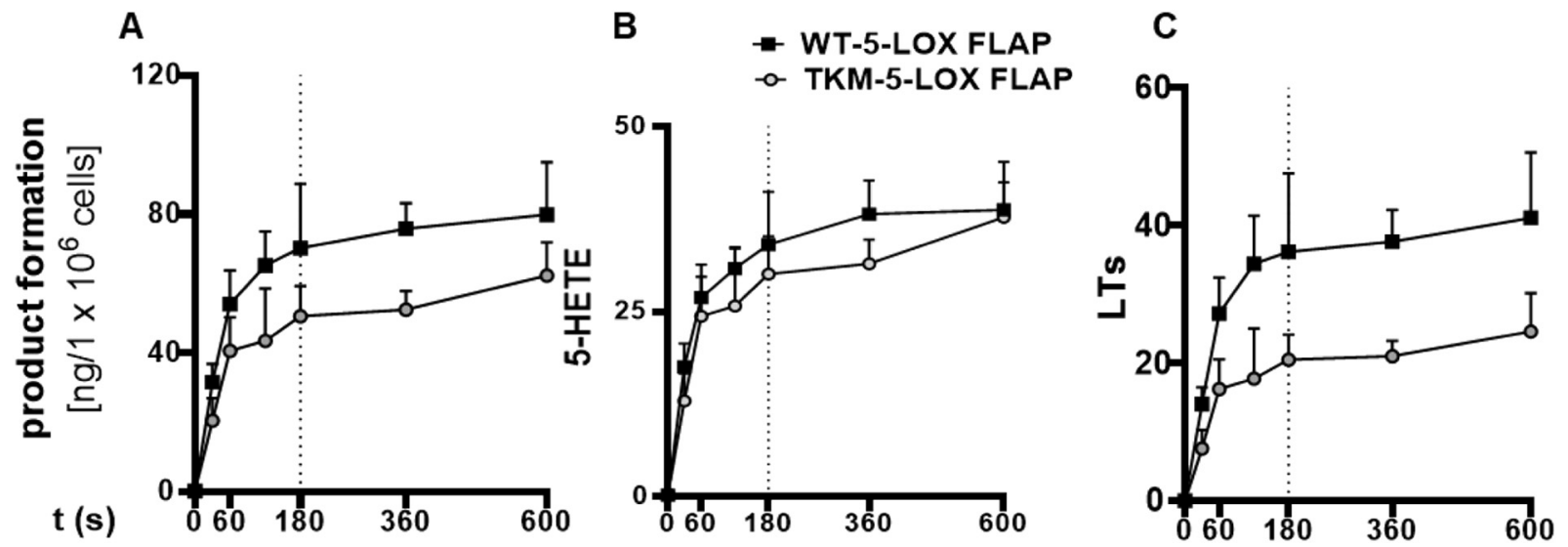

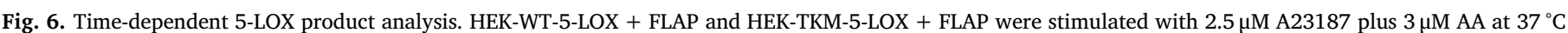

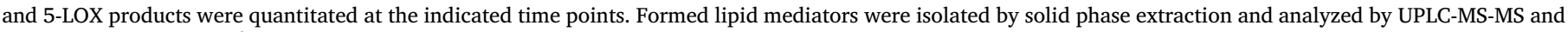
are shown as ng/1 $\times 10^{6}$ cells. (A) Total 5-LOX products (B) 5-HETE, (C) LTA 4 breakdown products. Results were analyzed in $n=3$ independent experiments.

expressing FLAP and TKM-5-LOX and stimulated with $\mathrm{Ca}^{2+}$-ionophore.

\section{Discussion}

\subsection{Structural impact of the triple-lysine motif}

The $\mathrm{KKK}^{653-655}$ sequence is located 20 -amino acids up stream of the C-terminal Ile673, which ligates the active site iron of 5-LOX via its main chain carboxyl. This unique sequence motif appears to conflict with salt-link and $\pi$-cation interactions observed in other LOX structures. K655 of the KKK motif in other LOXs is typically a conserved Leu. A highly conserved Arg651 lies one turn away on the C-terminal helix

A
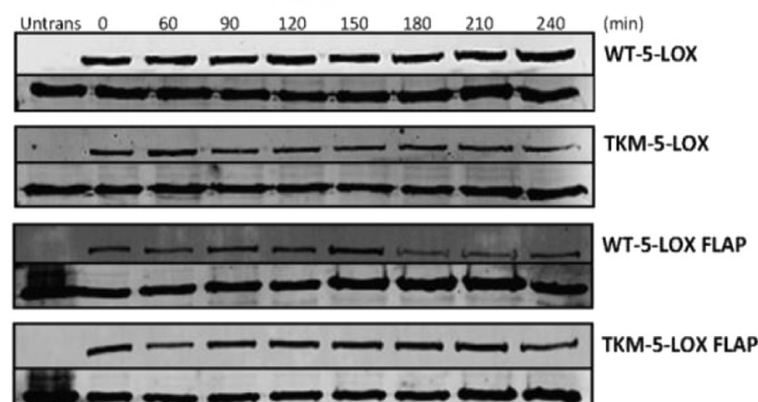

$+\mathrm{A} 23187$
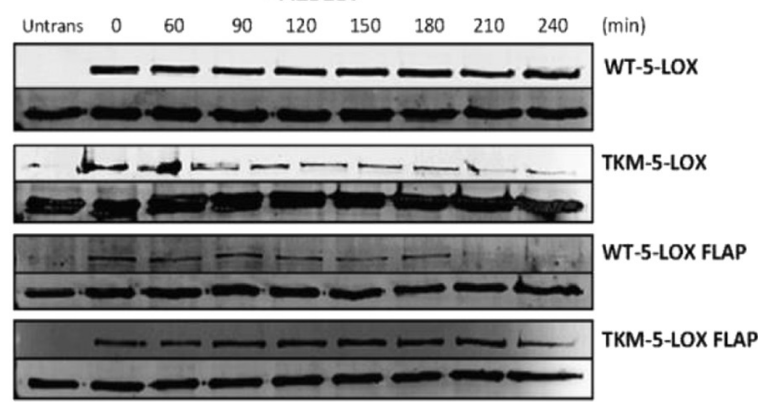

and participates in a conserved salt-link with Asp473 and a $\pi$-cation interaction with Phe469 [24]. Thus, a Lys at 655 in WT-5-LOX may disrupt these interactions and impact the positioning of the C-terminal Ile673 carboxyl in the $\mathrm{Fe}^{2+}$ coordination sphere. The structure of a bacterial LOX that harbors a positively charged amino acid at the position corresponding to 5-LOX Lys655 confirmed this prediction: the invariant Arg (Arg651) that participates in a conserved salt link has been displaced in this enzyme [29].

The mutation of the KKK to ENL was performed to engineer a 5-LOX variant for crystallographic studies, and it was observed that the mutation increased the melting temperature of the mutant protein [24]. This led us to suggest that the KKK motif might contribute to an

B
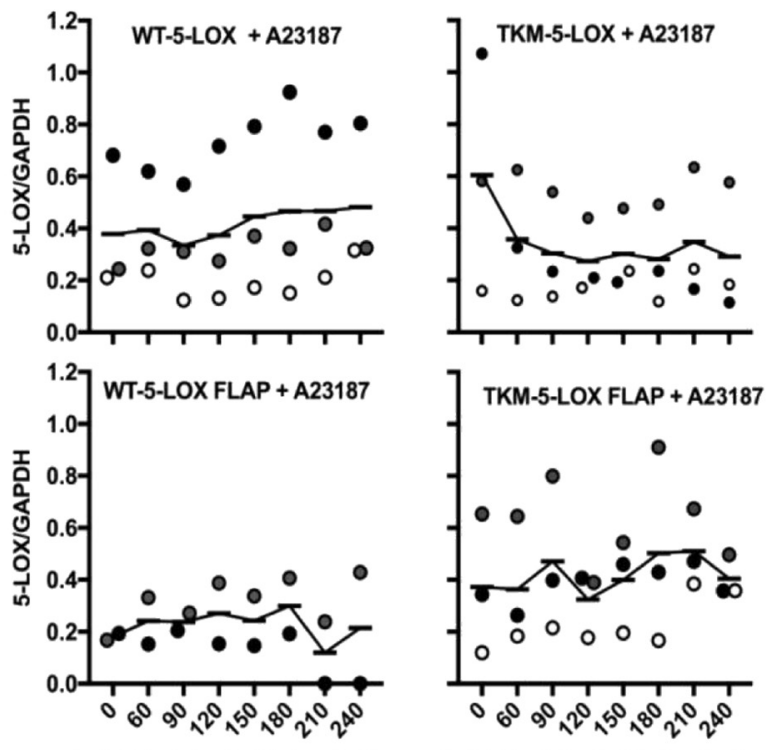

(min) Cycloheximide Incubation (min) Cycloheximide Incubation

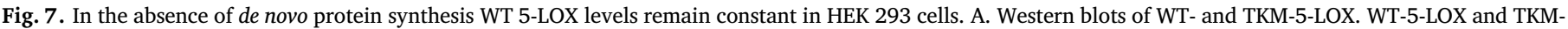

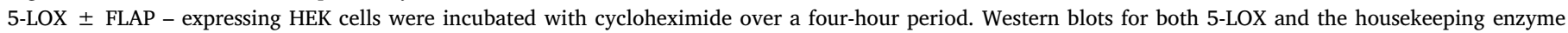

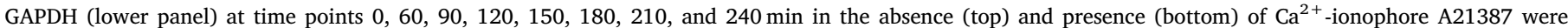

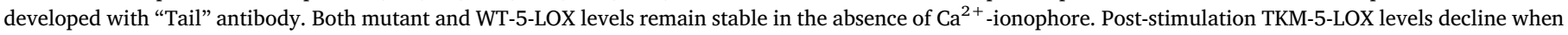

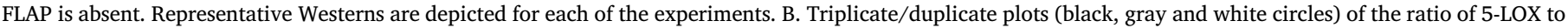

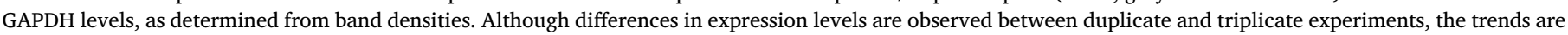

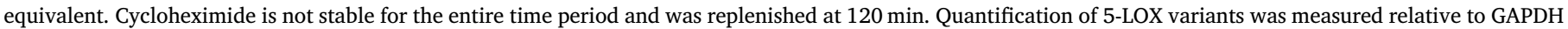

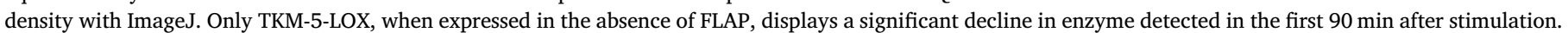




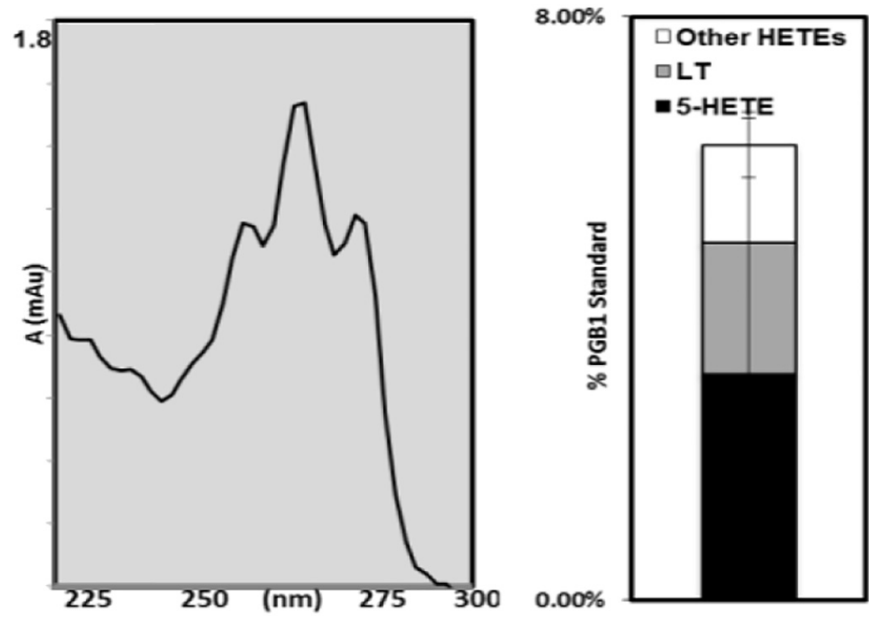

Fig. 8. TKM-5-LOX FLAP expressing cells produce LT from endogenous AA. (Left) The UV-spectrum of the gray fraction is consistent with LTA $_{4}$ hydrolysis products. (Right) Overall proportions of extracted oxylipins from TKM-5-LOX FLAP cells stimulated with $\mathrm{Ca}^{2+}$-ionophore A21387.

atypically short half-life compared to other LOXs [22]. TKM-5-LOX is indeed less susceptible to protease than the wild-type as the purified enzyme, or in crude cell lysates. However, we observed that the levels of both WT-5-LOX and TKM-5-LOX remain stable in unstimulated HEK cells, despite the pronounced instability of the former under cell-free conditions. In experiments to determine if the increased stability of TKM-5-LOX is reflected as a longer half-life in a cellular context we monitored enzyme levels in cells in which protein synthesis was inhibited. In the absence of stimulation the band densities for the WT- and TKM-5-LOX remain stable in the presence or absence of FLAP over $4 \mathrm{~h}$. Thus, the protease sensitivity of the WT enzyme observed in cell-free conditions does not appear to affect protein levels in a cellular context, and the increased activity of TKM-5-LOX in intact HEK cells is not simply due to higher levels of enzyme expression or longer half-life.

In contrast, inclusion of $\mathrm{Ca}^{2+}$-ionophore that enables the enzyme to access liberated endogenous AA, leads to a loss of the TKM-5-LOX protein levels in cells devoid of FLAP in the first 90 min of incubation. In contrast, in cells expressing WT-5-LOX \pm FLAP or TKM-5-LOX with FLAP, LOX levels remained stable. Thus, only the hyperactive TKM mutant levels decay, suggesting that the loss of TKM-5-LOX is a consequence of catalysis, as is consistent with the increased products generated by TKM-5-LOX with exogenously added AA. Notably, in the absence of exogenous AA there is sufficient endogenous AA released by the action of $\mathrm{PLA}_{2}$ to observe enzyme activity, and its consequent decay. In those cells that generate lower levels of product, 5-LOX enzyme levels remain stable.

\subsection{The presence of FLAP equalizes the capacities to generate 5-LOX products}

We have demonstrated that the $\mathrm{KKK}^{653-655}$ sequence is a unique 5LOX structural feature that acts as an intrinsic regulator of 5-LOX to control the flow of LT biosynthesis. In the absence of FLAP, we observed a striking difference in the activities of the WT- and TKM-5-LOX. The KKK motif severely constrains a robust LOX activity as observed by the $\sim 20$-fold increase in product formation when the KKK sequence is substituted by ENL (Fig. 5), and this 20 -fold increase cannot be explained by differences in enzyme expression levels or enzyme half-life. However, this increase in activity is not apparent when TKM-5-LOX is co-expressed with FLAP (Figs. 5, 6). In these conditions, 5-LOX product levels of WT- and TKM-5-LOX are roughly equivalent. While differences in total $\mathrm{LTA}_{4}$ hydrolysis products were observed at intermediate time points in the cell incubations, this difference is not significant after
10 min of incubation.

While the presence of FLAP increases the LT biosynthetic capacity of the WT-5-LOX-expressing cells, the TKM-5-LOX-expressing cells display a significantly reduced LT biosynthetic efficiency when FLAP is present. Interestingly, the pronounced increase in product formation by TKM-5LOX is only apparent in incubations with intact cells, as assays of cell homogenates have similar product yields (Fig. 5c). Similarly, the impact of FLAP on 5-LOX product formation is only observed in intact cells [7]. The presence of an intact nuclear membrane may be essential for both processes.

It is tempting to speculate on how the presence of FLAP equalizes the product levels for WT- and TKM-5-LOX. Our data may suggest that the transfer of AA from FLAP to 5-LOX is the rate-limiting step of the transformation of AA to LTA 4 . For the WT-5-LOX, FLAP increases its access to substrate. However, the more robust activity of TKM is obscured when it must access FLAP-sequestered AA. FLAP serves as a gatekeeper. An alternative model is that a FLAP-induced conformational change in 5-LOX abrogates the effect of the KKK to ENL mutation by constraining the conformations it can sample in catalysis. For example, any effect of the mutation on the $\mathrm{Fe}^{2+}$ coordination sphere may be negated once 5-LOX and FLAP interact. Either model is consistent with the suggestion that a specific FLAP:5-LOX interaction allows FLAP to rescue 5-LOX mutants with impaired enzyme and membrane-binding activities [11].

In intact cells FLAP is able to compensate for the lower activity of the WT-5-LOX to some extent. Thus, we suggest that the KKK motif confers the requirement for FLAP for rapid initiation of LT biosynthesis. This regulatory mechanism is reminiscent of the cyclin/cyclin-dependent kinase scenario, where an enzyme (the kinase) requires interaction with a binding partner to promote catalytic competence [30]. Overproduction of LTs as pro-inflammatory mediators is detrimental to the organism, thus the tempered activity of 5-LOX that relies on alleviation by a protein partner limits this possibility. WT-5-LOX alone is particularly inefficient at producing lipid mediators but stimulated by FLAP it still does not reach the levels produced by the TKM-5-LOX expressed without FLAP. The fact that the presence of FLAP obviates the marked increase in 5-LOX product formation by TKM-5-LOX suggests that the KKK motif is not required for interaction with FLAP.

\subsection{Turnover based inactivation}

By monitoring 5-LOX protein levels in the presence of an inhibitor of protein biosynthesis, we observed a turnover-dependent loss of TKM-5LOX. In the absence of $\mathrm{Ca}^{2+}$-ionophore, both WT- and TKM-5-LOX exhibited stable protein levels. However, in the presence of $\mathrm{Ca}^{2+}$-ionophore there is a decline in the level of TKM-5-LOX detected in intact cells after $90 \mathrm{~min}$ (Fig. 7). The cycloheximide analysis was performed without addition of exogenous AA. However, we can detect the products of TKM-5-LOX activity in $\mathrm{Ca}^{2+}$-ionophore-stimulated HEK cells without addition of exogenous AA (Fig. 8) and confirm that endogenous AA is released from the phospholipids upon stimulation. The presence of endogenous phospholipid-esterified AA that might provide a source of substrate is supported by data from other groups. Dawaliby et al. established that HEK293 cell membranes contain C20 containing phospholipids [31]. More specifically, Zhu et al. [32] report the presence of 20:4n-6 fatty acids in the cell membrane phospholipids of HEK293 cells. Additionally, HEK cells transfected to express 12-LOX generate product without the addition of exogenous AA when cultured in DMEM [27]. Therefore, the elevated product levels detected in HEK cells expressing TKM-5-LOX in the presence of exogenous AA and the disappearance of TKM-5-LOX, once stimulated with $\mathrm{Ca}^{2+}$-ionophore to promote release of endogenous PL-esterified AA, are consistent with turnover-based inactivation. 


\subsection{Intrinsic regulators}

The KKK motif might be an integral deactivation sequence that acts as a regulator of LT biosynthesis. Internal enzyme fail-safe mechanisms are one of many regulatory mechanisms that keep the intricate web of biosynthetic pathways in check. An intriguing auto-inactivation mechanism of another LT biosynthetic enzyme has been described for LTA $_{4}$ hydrolase. In this enzyme, the presence of Tyr378 makes it susceptible to covalent modification by its reactive substrate. Substitution of Tyr378 with Gln or Ala leads to a variant that is less susceptible to covalent modification, and consequently inactivation, by the substrate [33-35]. Thus, both 5-LOX and $\mathrm{LTA}_{4}$ hydrolase display auto-suppression of catalytic activity, but through entirely different mechanisms.

Other amino acids in 5-LOX have been demonstrated to play significant roles in tempering a robust rate of product formation. Rakonjac et al. examined the significance of a salt-link between residues Arg101 and Asp166 of the regulatory and catalytic domains, respectively. Disruption of this interaction leads to an increase in enzyme activity [36].

Our studies do not reveal exactly how the presence of the KKK motif modulates 5-LOX activity. Computational methods, as summarized by O'Rourke et al., can be combined with high-resolution X-ray data to reveal possible internal protein communication networks [37]. However, the resolution of the crystal structure of Stable-5-LOX makes this approach inaccessible at this point. In any case, it is apparent that the KKK motif significantly contributes to tight regulation of 5-LOX activity as the initiator of LT biosynthesis. This motif, which initially we studied as a possible mechanism to limit protein half-life, appears to be part of a more intricate, finely-tuned control mechanism to regulate LT biosynthesis in conjunction with FLAP.

\section{Materials and methods}

\subsection{Materials}

The "Tail" antibody was generated by Genscript (Piscataway) to a peptide with the C-terminal 12 amino acids of 5-LOX: CSPDRIPNSVAI. Specificity was confirmed by its ability to detect full-length bacterially expressed Stable-5-LOX, but not a truncated version of the construct. 5LOX "Body" was purchased from Abcam and is raised to the sequence QHRRKELETRQKQYRWMEWN (amino acid 130-149). FLAP antibody was purchased from Abcam (Cambridge) and secondary antibodies were obtained from Life Technologies (Carlsbad, CA).

\subsection{5-LOX purification}

His-tagged WT-5-LOX and TKM-5-LOX were expressed in Rosetta cells with a pET14B vector. Bacteria were cultured at $37^{\circ} \mathrm{C}$ and $220 \mathrm{rpm}$ for $4 \mathrm{~h}$ and then at $20^{\circ} \mathrm{C}$ for an additional $27 \mathrm{~h}$. Cells expressing WT-5LOX were lysed by sonication and the lysate was clarified by centrifugation at $36,000 \times g$ for $30 \mathrm{~min}$. To the supernatant was added ammonium sulfate to $50 \%$ saturation. The precipitant was pelleted and resuspended in $100 \mathrm{mM}$ Tris, $100 \mathrm{mM} \mathrm{NaCl}, 5 \mathrm{mM}$ Imidazole, $2 \mathrm{mM}$ tris (2-carboxyethyl)phosphine (TCEP), $10 \mu \mathrm{M} \mathrm{FeSO}$. The resuspended precipitant was applied to a $\mathrm{Co}^{2+}$-affinity column. The column was washed with $100 \mathrm{mM}$ Tris, $100 \mathrm{mM} \mathrm{NaCl}, 2 \mathrm{mM}$ TCEP, $10 \mu \mathrm{M} \mathrm{FeSO}_{4}$, $20 \mathrm{mM}$ imidazole and the immobilized enzyme eluted with $100 \mathrm{mM}$ Tris, $100 \mathrm{mM} \mathrm{NaCl}, 2 \mathrm{mM}$ TCEP, $10 \mu \mathrm{M} \mathrm{FeSO}, 10 \mu \mathrm{g} / \mathrm{ml}$ catalase, $200 \mathrm{mM}$ imidazole. After concentration of the eluant, protein concentration was determined with a Nanodrop spectrophotometer. Protein purity was confirmed by SDS-PAGE. Purified protein was frozen dropwise and stored in liquid $\mathrm{N}_{2}$.

\subsection{TKM-5-LOX purification}

Bacterial cell cultures prepared as above were lysed by French press.
After clarification of the lysate by centrifugation at $36,000 \times g$, the supernatant was applied to a $\mathrm{Co}^{2+}$-affinity column. The column was washed with $100 \mathrm{mM}$ Tris, $500 \mathrm{mM} \mathrm{NaCl}, 20 \mathrm{mM}$ imidazole. The immobilized enzyme was eluted with $100 \mathrm{mM}$ Tris, $500 \mathrm{mM} \mathrm{NaCl}$, $200 \mathrm{mM}$ imidazole. After concentration of the eluent, protein concentration was determined with a Nanodrop spectrophotometer. Protein purity was confirmed by SDS-PAGE. Purified protein was frozen dropwise and stored in liquid $\mathrm{N}_{2}$.

\subsection{Expression of 5-LOX and FLAP in HEK293 cells}

HEK293 cells were transfected with WT-5-LOX, TKM-5-LOX, and FLAP using the pcDNA3.1 vector for stable protein expression as described by Gerstmeier et al. [27]. Cells were cultured at $37^{\circ} \mathrm{C}, 5 \% \mathrm{CO}_{2}$ in Dubelco's Modified Eagle Medium (DMEM) with 10\% fetal bovine serum (FBS, Atlanta Biologicals), in the presence of selection antibiotic (G418, 5-LOX; and hygromycin, FLAP (both from Sigma)). Successful protein expression was confirmed by Western blotting.

\subsection{Proteolytic cleavage}

\subsubsection{Purified enzyme}

Purified WT- and TKM-5-LOX were diluted to $9.8 \mu \mathrm{M}$ in $100 \mathrm{mM}$ Tris, $100 \mathrm{mM} \mathrm{NaCl}$. The purified protein solutions were incubated with or without $2.5 \mu \mathrm{M} \mathrm{CaCl}_{2}$ for $5 \mathrm{~min}$. The solutions were then incubated with or without $5 \mu \mathrm{M}$ chymotrypsin (2:1 protein to protease ratio) for $1 \mathrm{~min}$ on ice. Samples were run on an SDS-PAGE gel and transferred to a PVDF membrane with a Bio-Rad Trans-Blot system for Western development. The primary antibodies were rabbit anti-5-LOX "Body" (amino acids 130-149) and rabbit anti-5-LOX "Tail" (12 amino acids from the C-terminus). The secondary antibody utilized was goat anti-rabbit AlexFlour647. Western blots were imaged with a Typhoon 9410 imager using channel $67030 \mathrm{BP}$.

\subsubsection{Cell lysates}

HEK293 cells expressing WT- or TKM-5-LOX were collected and resuspended at $1 \times 10^{6} \mathrm{cells} / \mathrm{ml}$ in phosphate-buffered saline (PBS) plus $0.1 \%$ glucose. Cells were incubated with or without $2.5 \mu \mathrm{M} \mathrm{Ca}^{2+}$. ionophore A23187 for $5 \mathrm{~min}$ in a $37^{\circ} \mathrm{C}$ water bath. The cells were spun down and resuspended in lysis buffer $(50 \mathrm{mM}$ Tris pH 8.0, $150 \mathrm{mM}$ $\mathrm{NaCl}, 1 \mathrm{mM}$ EDTA, $2 \%$ Triton- $\times 100$ ) before being incubated with $100 \mathrm{nM}$ chymotrypsin for $1 \mathrm{~min}$ on ice. Sample protein concentrations were determined with a BCA protein assay kit (Pierce). Equivalent amounts of protein were loaded onto $10 \%$ SDS-PAGE gels. After blotting onto PVDF membranes. The resulting Western blots were developed as described above.

\subsection{5-LOX HPLC product analysis of HEK cells}

HEK293 cells expressing WT- or TKM-5-LOX with or without FLAP were collected and resuspended at $1 \times 10^{6}$ cells $/ \mathrm{ml}$ PBS plus $0.1 \%$ glucose. Each sample was incubated with or without $2.5 \mu \mathrm{M} \mathrm{Ca}^{2+}$-ionophore A23187 for $5 \mathrm{~min}$ at $37^{\circ} \mathrm{C}$ then incubated for $10 \mathrm{~min}$ with $3 \mu \mathrm{M}$ AA (Cayman). Modest substitutions have been shown to effect the kinetics of 5-LOX translocation to the nuclear membrane [11] and preincubation with ionophore was necessary to control for any differences in membrane trafficking that might result from the substitution of the KKK motif. Incubations were stopped with the addition of $1 \mathrm{ml}$ (1 volume) of methanol. Prior to solid phase extraction with C18 cartridges (UCT CLEAN-UP C18 CEC1811Z), $0.5 \mathrm{ml} \mathrm{PBS}, 30 \mu \mathrm{l}$ of $1 \mathrm{M} \mathrm{HCl}$, and $10 \mu \mathrm{l}$ of $50 \mathrm{ng} / \mu \mathrm{l}$ prostaglandin $\mathrm{B}_{1}$ (Cayman, $\mathrm{PGB}_{1}$ ) were added. The products were eluted with methanol. The methanol was evaporated off under $\mathrm{N}_{2}$ gas and the residue was resuspended in $60 \%$ acetonitrile, $0.1 \%$ formic acid, the HPLC mobile phase. Samples were treated with triphenylphosphine as a reducing agent prior to HPLC analysis. Isocratic reverse-phase HPLC was performed with a Supelco Discovery 
HSC18 column monitored at 235 and $270 \mathrm{~nm}$. Peaks for 5-HETE $(235 \mathrm{~nm})$ and $\mathrm{PGB}_{1}(270 \mathrm{~nm})$ were integrated. The peaks corresponding to $\mathrm{LTA}_{4}$-derived breakdown products such as trans-LTB $\mathrm{L}_{4}$ or the $5,6 \mathrm{di}$ HETE were identified by their characteristic UV fine structure, integrated, summed and reported as LT. Product yields were calculated relative to the peak area of the internal standard $\mathrm{PGB}_{1}$. Activity analysis for HEK cells expressing TKM-5-LOX and FLAP with only endogenous AA pools was performed in the same fashion as above (but without added AA) and 5 incubations were pooled for solid phase extraction of products (Fig. 8). Statistical analysis was performed in GraphPad Prism v.7 (GraphPad Software, La Jolla, CA).

\subsection{5-LOX product analysis of HEK cells analyzed by UPLC-MS-MS}

HEK-WT-5-LOX + FLAP and HEK-TKM-5-LOX + FLAP cells $\left(1 \times 10^{6} / \mathrm{ml}\right)$ were incubated in PBS containing $1 \mathrm{mM} \mathrm{CaCl}_{2}$. Cells were stimulated with $2.5 \mu \mathrm{M}$ A23187 plus $3 \mu \mathrm{M} \mathrm{AA}$ at $37^{\circ} \mathrm{C}$ and sampled at 0 , $30,60,120,180,360$ and $600 \mathrm{~s}$. Ice-cold methanol ( $2 \mathrm{ml})$ was added to the samples to stop the reaction along with $10 \mu \mathrm{l}$ of deuterium-labelled internal standards $(200 \mathrm{nM}$ d8-5S-HETE, d4-LTB 4 ) to facilitate quantification and sample recovery. Sample preparation was conducted by adapting published criteria $[38,39]$. Samples were kept at $-20^{\circ} \mathrm{C}$ for $60 \mathrm{~min}$ to allow protein precipitation. After centrifugation $(1200 \times \mathrm{g}$, $4{ }^{\circ} \mathrm{C}, 10 \mathrm{~min}$ ) $8 \mathrm{ml}$ acidified $\mathrm{H}_{2} \mathrm{O}$ was added (final $\mathrm{pH}=3.5$ ) and the sample was subjected to solid phase extraction. Solid phase cartridges (Sep-Pak ${ }^{\circledast}$ Vac 6 cc $500 \mathrm{mg} / 6 \mathrm{ml}$ C18; Waters, Milford, MA) were equilibrated with $6 \mathrm{ml}$ methanol and $2 \mathrm{ml} \mathrm{H}_{2} \mathrm{O}$ before samples were loaded onto columns. After washing with $6 \mathrm{ml} \mathrm{H}_{2} \mathrm{O}$ and additional $6 \mathrm{ml}$ hexane, lipid mediators were eluted with $6 \mathrm{ml}$ methyl formate. Finally, the samples were brought to dryness using an evaporation system (TurboVap LV, Biotage, Uppsala, Sweden) and resuspended in $100 \mu \mathrm{l}$ methanol-water $(50 / 50, \mathrm{v} / \mathrm{v})$ for UPLC-MS-MS automated injections. Lipid mediator profiling was analyzed with an Acquity ${ }^{\mathrm{TM}}$ UPLC system (Waters, Milford, MA, USA) and a QTRAP 5500 Mass Spectrometer (ABSciex, Darmstadt, Germany) equipped with a Turbo $\mathrm{V}^{\mathrm{TM}}$ Source and electrospray ionization (ESI). Lipid mediators were eluted using an ACQUITY UPLC ${ }^{\otimes}$ BEH C18 column $(1.7 \mu \mathrm{m}, 2.1 \times 100 \mathrm{~mm}$; Waters, Eschborn, Germany) at $\mu$ phase consisting of methanol-water-acetic acid of 42:58:0.01 (v/v/v) that was ramped to 86:14:0.01 (v/v/v) over $12.5 \mathrm{~min}$ and then to $98: 2: 0.01(\mathrm{v} / \mathrm{v} / \mathrm{v})$ for $3 \mathrm{~min}$ [40]. The QTrap 5500 was operated in negative ionization mode using scheduled multiple reaction monitoring (MRM) coupled with information-dependent acquisition. The scheduled MRM window was $60 \mathrm{~s}$, optimized lipid mediator parameters were adopted (CE, EP, DP, CXP), and the curtain gas pressure was set to $35 \mathrm{psi}$. The retention time and at least six diagnostic ions for each lipid mediator were confirmed by means of an external standard (Cayman Chemicals/Biomol, Hamburg Germany). Quantification was achieved by calibration curves for each of the lipid mediators analyzed. Linear calibration curves were obtained that gave $\mathrm{r}^{2}$ values of 0.998 or higher (for fatty acids 0.95 or higher).

\subsection{Immunofluorescence imaging of 5-LOX and FLAP in HEK293 cells}

HEK293 cells expressing WT- or TKM-5-LOX with or without FLAP were seeded out at 200 cells $/ \mathrm{ml}$ in each well of an Ibdi 12-well slide. After $24-48 \mathrm{~h}$ at $37{ }^{\circ} \mathrm{C} 5 \% \mathrm{CO}_{2}, 2.5 \mu \mathrm{M} \mathrm{Ca}^{2+}$-ionophore A23187 was added to stimulate the cells, which were then incubated for $5 \mathrm{~min}$ at $37^{\circ} \mathrm{C} 5 \% \mathrm{CO}_{2}$. The cells were fixed with $4 \%$ paraformaldye then washed 3 times with PBS. The cells were then incubated with a $50 \mathrm{mM} \mathrm{NH}_{4} \mathrm{Cl}$ solution, followed by a wash cycle and subsequently blocked for an hour with $10 \%$ donkey serum, $0.1 \%$ Tween-20 in PBS. The samples were then incubated overnight at $4{ }^{\circ} \mathrm{C}$ with a primary antibody solution consisting of either rabbit anti-5-LOX "Body" \pm goat anti-FLAP or rabbit anti-5-LOX "Tail" \pm goat anti-FLAP in $0.1 \%$ Tween-20 PBS solution. After a wash cycle with $0.1 \%$ Tween-20 PBS the cells were incubated with a secondary antibody solution consisting of donkey anti- rabbit AlexaFluor488 \pm donkey anti-goat AlexaFluor647 in a $0.1 \%$ Tween-20 PBS solution for $20 \mathrm{~min}$. After another wash cycle, the cells were incubated with $2 \mu \mathrm{g} / \mu \mathrm{l}$ DAPI solution for $3 \mathrm{~min}$ followed by another wash cycle. Invitrogen Prolong Gold antifade reagent and a coverslip were then added to the slide. The slide was imaged with a Leica DM6B upright microscope using DAPI, GFP (5-LOX), and Cy5 (FLAP) filters.

\subsection{HEK cell protein time-course in the absence of protein synthesis}

HEK cells expressing WT- or TKM-5-LOX with or without FLAP were collected and resuspended at $1 \times 10^{6}$ cells $/ \mathrm{ml}$ in PBS plus $0.1 \%$ glucose. The cells were incubated with or without $2.5 \mu \mathrm{M} \mathrm{Ca}^{2+}$-ionophore A23187 for $5 \mathrm{~min}$ and then treated with $200 \mu \mathrm{M}$ cycloheximide at $37^{\circ} \mathrm{C}$ and analyzed at eight time points $(0,60,90,120,150,180,210$, and $240 \mathrm{~min}$ ). An extra $200 \mu \mathrm{M}$ cycloheximide was added after $120 \mathrm{~min}$ to ensure continuous inhibition of protein synthesis. At each time point $2 \times 10^{6}$ cells were treated with lysis buffer $(50 \mathrm{mM}$ Tris $\mathrm{pH} 8.0$, $150 \mathrm{mM} \mathrm{NaCl}, 1 \mathrm{mM}$ EDTA, $2 \%$ Triton X-100, $1 \mu \mathrm{M}$ peptstatin, leupeptin and PMSF). Sample protein concentrations were determined with a BCA assay and equal amounts of protein were loaded onto $10 \%$ SDS-PAGE gels. The samples were then analyzed by Western blot using rabbit anti-5-LOX "Tail" and goat anti-GAPDH primary antibodies and donkey anti-rabbit AlexaFluor488 and donkey anti-goat AlexaFluor647 secondary antibodies. Western blots were imaged with a Typhoon 9410 imager using channels 526 SP and 67030 BP. For quantitative analysis of western bands we used ImageJ software.

\subsection{0. qPCR HEK 5-LOX mRNA quantification}

\subsubsection{RNA isolation}

Samples of $1 \times 10^{7}$ cells were collected for each of the four cell lines, i.e., WT- or TKM-5-LOX with and without FLAP. After spinning down cells and removing the media, the cells were resuspended in Trizol Reagent and incubated for $5 \mathrm{~min}$ at room temperature. Then, a $50 / 50$ mixture of chloroform and isoamyl alcohol was mixed with the samples and allowed to incubate for $3 \mathrm{~min}$ at room temperature. After centrifugation, the upper aqueous phase of the samples was transferred to a fresh tube. Isopropanol was mixed with aqueous phase and incubated for $10 \mathrm{~min}$ at room temperature. The samples were again centrifuged and the RNA pellet was washed twice with 75\% ethanol and then let to air dry. The RNA pellets were then dissolved in diethylpyrocarbonate (DEPC) water before undergoing DNase treatment where the samples were incubated with DNase I at $37^{\circ} \mathrm{C}$ for $30 \mathrm{~min}$ then with the addition of $10 \mathrm{mM}$ EDTA incubated at $70^{\circ} \mathrm{C}$ for $10 \mathrm{~min}$. Next, the samples were incubated with $300 \mathrm{mM}$ sodium acetate and 2.5 volumes of ethanol at $-80^{\circ} \mathrm{C}$ for $15 \mathrm{~min}$ before being centrifugation at $4{ }^{\circ} \mathrm{C}$ for $10 \mathrm{~min}$. The RNA pellets were dissolved in DEPC water and concentration readings were taken by Nanodrop.

\subsection{2. cDNA synthesis and gel analysis}

The isolated RNA $(10 \mu \mathrm{g})$ served as a template for cDNA synthesis using the Goscript reverse transcriptase kit (Promega). Forward and reverse oligos for 5-LOXs and the GAPDH control were made by Integrated DNA Technologies (IDT) (Fig. S4). Samples were then treated with RNaseH before undergoing PCR. The PCR samples were run on an Agarose gel and analyzed visually. For quantitative analysis we used ImageJ software.

\section{Abbreviations \\ 5-LOX 5-lipoxygenase \\ FLAP 5-lipoxygenase activating protein \\ $\mathrm{PLA}_{2}$ phospholipase A2 \\ AA arachidonic acid \\ HETE hydroxyeicosatetraenoic acid}


HPETE hydro-peroxyeicosatetraenoic

PGB1 prostaglandin B1

LT leukotriene

TCEP tris(2-carboxy-ethyl)phosphine

DAPI 2-(4-Amidino-phenyl)-1H-indole-6-carboxamidine

UPLC Ultra Performance Liquid Chromatography

\section{Transparency document}

The Transparency document associated with this article can be found, in online version.

\section{Acknowledgements}

This work was supported by National Institutes of Health (HL 107887) and the American Heart Association (16GRNT31000010) to M.E.N., the Deutsche Forschungsgemeinschaft (GA-2101/2-1) to U.G. and the Carl Zeiss Foundation (to J.G.).

\section{Conflict of interest}

The authors declare that they have no conflicts of interest with the contents of this article.

\section{Appendix A. Supplementary data}

Supplementary data to this article can be found online at https:// doi.org/10.1016/j.bbalip.2018.09.011.

\section{References}

[1] J.Z. Haeggstrom, C.D. Funk, Lipoxygenase and leukotriene pathways: biochemistry, biology, and roles in disease, Chem. Rev. 111 (2011) 5866-5898.

[2] O. Radmark, O. Werz, D. Steinhilber, B. Samuelsson, 5-Lipoxygenase, a key enzyme for leukotriene biosynthesis in health and disease, Biochim. Biophys. Acta 1851 (2015) 331-339.

[3] C.A. Rouzer, B. Samuelsson, Reversible, calcium-dependent membrane association of human leukocyte 5-lipoxygenase, Proc. Natl. Acad. Sci. U. S. A. 84 (1987) 7393-7397.

[4] J.W. Woods, J.F. Evans, D. Ethier, S. Scott, P.J. Vickers, L. Hearn, J.A. Heibein, S. Charleson, I.I. Singer, 5-Lipoxygenase and 5-lipoxygenase-activating protein are localized in the nuclear envelope of activated human leukocytes, J. Exp. Med. 178 (1993) 1935-1946.

[5] R.A.F. Dixon, R.E. Diehl, E. Opas, E. Rands, P.J. Vickers, J.F. Evans, J.W. Gillard, D.K. Miller, Requirement of a 5-lipoxygenase-activating protein for leukotriene synthesis, Nature 343 (1990) 282-284.

[6] G.K. Reid, S. Kargman, P.J. Vickers, J.A. Mancini, C. Leveille, D. Ethier, D.K. Miller, J.W. Gillard, R.A. Dixon, J.F. Evans, Correlation between expression of 5-lipoxygenase-activating protein, 5-lipoxygenase, and cellular leukotriene synthesis, J. Biol. Chem. 265 (1990) 19818-19823.

[7] J.F. Evans, A.D. Ferguson, R.T. Mosley, J.H. Hutchinson, What's all the FLAP about?: 5-Lipoxygenase-activating protein inhibitors for inflammatory diseases, Trends Pharmacol. Sci. 29 (2008) 72-78.

[8] A.D. Ferguson, B.M. McKeever, S. Xu, D. Wisniewski, D.K. Miller, T.T. Yamin, R.H. Spencer, L. Chu, F. Ujjainwalla, B.R. Cunningham, J.F. Evans, J.W. Becker, Crystal structure of inhibitor-bound human 5-lipoxygenase-activating protein, Science 317 (2007) 510-512.

[9] B. Samuelsson, C.A. Rouzer, T. Matsumoto, Human leukocyte 5-lipoxygenase: an enzyme possessing dual enzymatic activities and a multicomponent regulatory system, Adv. Prostaglandin Thromboxane Leukot. Res. 17A (1987) 1-11.

[10] T. Shimizu, O. Radmark, B. Samuelsson, Enzyme with dual lipoxygenase activities catalyzes leukotriene A4 synthesis from arachidonic acid, Proc. Natl. Acad. Sci. U. S. A. 81 (1984) 689-693.

[11] J. Gerstmeier, M.E. Newcomer, S. Dennhardt, E. Romp, J. Fischer, O. Werz, U. Garscha, 5-Lipoxygenase-activating protein rescues activity of 5-lipoxygenase mutations that delay nuclear membrane association and disrupt product formation, FASEB J. 30 (2016) 1892-1900.

[12] A.M. Bair, M.V. Turman, C.A. Vaine, R.A. Panettieri Jr., R.J. Soberman, The nuclear membrane leukotriene synthetic complex is a signal integrator and transducer, Mol. Biol. Cell 23 (2012) 4456-4464.

[13] A.K. Mandal, J. Skoch, B.J. Bacskai, B.T. Hyman, P. Christmas, D. Miller, T.T. Yamin, S. Xu, D. Wisniewski, J.F. Evans, R.J. Soberman, The membrane organization of leukotriene synthesis, Proc. Natl. Acad. Sci. U. S. A. 101 (2004) 6587-6592.
[14] A.K. Mandal, P.B. Jones, A.M. Bair, P. Christmas, D. Miller, T.T. Yamin, D. Wisniewski, J. Menke, J.F. Evans, B.T. Hyman, B. Bacskai, M. Chen, D.M. Lee, B. Nikolic, R.J. Soberman, The nuclear membrane organization of leukotriene synthesis, Proc. Natl. Acad. Sci. U. S. A. 105 (2008) 20434-20439.

[15] E. De Carolis, D. Denis, D. Riendeau, Oxidative inactivation of human 5-lipoxygenase in phosphatidylcholine vesicles, Eur. J. Biochem. 235 (1996) 416-423.

[16] M.D. Percival, D. Denis, D. Riendeau, M.J. Gresser, Investigation of the mechanism of non-turnover-dependent inactivation of purified human 5-lipoxygenase. Inactivation by $\mathrm{H} 2 \mathrm{O} 2$ and inhibition by metal ions, Eur. J. Biochem. 210 (1992) 109-117.

[17] Y.Y. Zhang, M. Hamberg, O. Radmark, B. Samuelsson, Stabilization of purified human 5-lipoxygenase with glutathione peroxidase and superoxide dismutase, Anal. Biochem. 220 (1994) 28-35.

[18] D. Aharony, D.G. Redkar-Brown, S.J. Hubbs, R.L. Stein, Kinetic studies on the inactivation of 5-lipoxygenase by $5(\mathrm{~S})$-hydroperoxyeicosatetraenoic acid, Prostaglandins 33 (1987) 85-100.

[19] T. Yokomizo, K. Kato, K. Terawaki, T. Izumi, T. Shimizu, A second leukotriene B(4) receptor, BLT2. A new therapeutic target in inflammation and immunological disorders, J. Exp. Med. 192 (2000) 421-432.

[20] T. Shimizu, T. Yokomizo, T. Izumi, Leukotriene-B4 receptor and signal transduc tion, Ernst Schering Res. Found. Workshop (2000) 125-141.

[21] T. Yokomizo, T. Izumi, K. Chang, Y. Takuwa, T. Shimizu, A G-protein-coupled receptor for leukotriene B4 that mediates chemotaxis, Nature 387 (1997) 620-624.

[22] R.C. Murphy, M.A. Gijon, Biosynthesis and metabolism of leukotrienes, Biochem. J. 405 (2007) 379-395.

[23] A.W. Ford-Hutchinson, M. Gresser, R.N. Young, 5-Lipoxygenase, Annu. Rev. Biochem. 63 (1994) 383-417.

[24] N.C. Gilbert, S.G. Bartlett, M.T. Waight, D.B. Neau, W.E. Boeglin, A.R. Brash, M.E. Newcomer, The structure of human 5-lipoxygenase, Science 331 (2011) 217-219.

[25] D.B. Neau, N.C. Gilbert, S.G. Bartlett, W. Boeglin, A.R. Brash, M.E. Newcomer, The 1.85 A structure of an 8R-lipoxygenase suggests a general model for lipoxygenase product specificity, Biochemistry 48 (2009) 7906-7915.

[26] M.L. Oldham, A.R. Brash, M.E. Newcomer, Insights from the X-ray crystal structure of coral 8R-lipoxygenase: calcium activation via a C2-like domain and a structural basis of product chirality, J. Biol. Chem. 280 (2005) 39545-39552.

[27] J. Gerstmeier, C. Weinigel, D. Barz, O. Werz, U. Garscha, An experimental cellbased model for studying the cell biology and molecular pharmacology of 5-lipoxygenase-activating protein in leukotriene biosynthesis, Biochim. Biophys. Acta 1840 (2014) 2961-2969.

[28] C.L. Dai, J. Shi, Y. Chen, K. Iqbal, F. Liu, C.X. Gong, Inhibition of protein synthesis alters protein degradation through activation of protein kinase B (AKT), J. Biol. Chem. 288 (2013) 23875-23883.

[29] A. Garreta, S.P. Val-Moraes, Q. Garcia-Fernandez, M. Busquets, C. Juan, A. Oliver, A. Ortiz, B.J. Gaffney, I. Fita, A. Manresa, X. Carpena, Structure and interaction with phospholipids of a prokaryotic lipoxygenase from Pseudomonas aeruginosa, FASEB J. 27 (2013) 4811-4821.

[30] R. Suryadinata, M. Sadowski, B. Sarcevic, Control of cell cycle progression by phosphorylation of cyclin-dependent kinase (CDK) substrates, Biosci. Rep. 30 (2010) 243-255.

[31] R. Dawaliby, C. Trubbia, C. Delporte, C. Noyon, J.M. Ruysschaert, P. Van Antwerpen, C. Govaerts, Phosphatidylethanolamine is a key regulator of membrane fluidity in eukaryotic cells, J. Biol. Chem. 291 (2016) 3658-3667.

[32] G. Zhu, Q. Ou, T. Zhang, X. Jiang, G. Sun, N. Zhang, K. Wang, H. Fang, M. Wang, J. Sun, T. Ge, A more desirable balanced polyunsaturated fatty acid composition achieved by heterologous expression of Delta15/Delta4 desaturases in mammalian cells, PLoS One 8 (2013) e84871.

[33] M.J. Mueller, M.B. Andberg, B. Samuelsson, J.Z. Haeggstrom, Leukotriene A4 hydrolase, mutation of tyrosine 378 allows conversion of leukotriene A4 into an isomer of leukotriene B4, J. Biol. Chem. 271 (1996) 24345-24348.

[34] M.J. Mueller, M. Blomster, U.C. Oppermann, H. Jornvall, B. Samuelsson, J.Z. Haeggstrom, Leukotriene A4 hydrolase: protection from mechanism-based inactivation by mutation of tyrosine-378, Proc. Natl. Acad. Sci. U. S. A. 93 (1996) 5931-5935.

[35] L. Orning, J. Gierse, K. Duffin, G. Bild, G. Krivi, F.A. Fitzpatrick, Mechanism-based inactivation of leukotriene A4 hydrolase/aminopeptidase by leukotriene A4. Mass spectrometric and kinetic characterization, J. Biol. Chem. 267 (1992) 22733-22739.

[36] M. Rakonjac Ryge, M. Tanabe, P. Provost, B. Persson, X. Chen, C.D. Funk, A. Rinaldo-Matthis, B. Hofmann, D. Steinhilber, T. Watanabe, B. Samuelsson, O. Radmark, A mutation interfering with 5-lipoxygenase domain interaction leads to increased enzyme activity, Arch. Biochem. Biophys. 545 (2014) 179-185.

[37] K.F. O'Rourke, S.D. Gorman, D.D. Boehr, Biophysical and computational methods to analyze amino acid interaction networks in proteins, Comput. Struct. Biotechnol. J. 14 (2016) 245-251.

[38] C. Colas, S. Menezes, E. Gutierrez-Martinez, C.B. Pean, M.S. Dionne, P. Guermonprez, An improved flow cytometry assay to monitor phagosome acidification, J. Immunol. Methods 412 (2014) 1-13.

[39] J. Dalli, S. Ramon, P.C. Norris, R.A. Colas, C.N. Serhan, Novel proresolving and tissue-regenerative resolvin and protectin sulfido-conjugated pathways, FASEB J. 29 (2015) 2120-2136.

[40] O. Werz, J. Gerstmeier, S. Libreros, X. De la Rosa, M. Werner, P.C. Norris, N. Chiang, C.N. Serhan, Human macrophages differentially produce specific resolvin or leukotriene signals that depend on bacterial pathogenicity, Nat. Commun. 9 (2018) 59. 